\title{
FURTHER NOTES ON THE BIRDS OF SUDEST ISLAND, OR TAGULA, IN THE LOUISIADE GROUP.
}

\author{
By LORD ROTHSCHILD, F.R.S., Ph.D., and ERNST HARTERT, Ph.D.
}

TWENTy years ago Hartert published (Novitates Zoologicae, 1898, 1 pp. 521-532) a list of 42 species received from Albert S. Meek from Sudest Island, in which eight new species and subspecies were described. We have now received another collection from the same island, brought together, during Mr. Meek's illness and convalescence, by his experienced collectors, the brothers Eichhorn. It contains a number of forms quite new to the island, and additional skins of most of the others, after comparison with much new material arrived since 1898 , enables us to revise the identification of several others, and to separate some new forms. We have also used the opportunity of reviewing some groups of the genus Myiagra and the subspecies of Caprimulgus macrurus.

\section{Manucodia atra altera R. \& H.}

Manucodia ater altera Rothschild \& Hartert, Nov. Zool. 1903. pp. 84. 85 (Eastern New Guinea, Eastern Papuan Islands, Aru Islands. Type: Sudest Island).

Some fresh specimens fully bear out the differences stated in our original description. Mr. Ogilvie-Grant (Ibis, Jubilee Suppl. ii. 1915, pp. 6, 7) does not admit this race because, as he puts it, "the difference is trifling." The differences, however, are easily seen, when comparing a series of the two subspecies, and confirmed by careful measuring. Possibly the Aru form should again be separated, if sufficient material could be measured.

\section{Corvus coronoides orru Bp.}

The specimens from the Louisiade Islands and S.E. New Guinea which we have received show a stronger metallic purplish gloss than others, but possibly this may be due to the freshness of the skins in plumage and age. We adopt the nomenclature of Stresemann, as proposed in Verh. Orn. Ges. Bayern. xii. p. 282.

\section{Dicrurus bracteatus dejectus (Hart.).}

Chibia carbonaria dejecta Hartert, Nov. Zool. 1898. p. 522 (Sudest Island).

An additional series of eight specimens fully bears out the differences of this subspecies. Hartert does not now separate the genus Chibia, and he treats dejectus and other allies not only as forms of carbonarius, but also of bracteatus.

\section{Aplonis cantoroides (Gray).}

Calornis cantoroides Gray, Proc. Zool. Soc. London, 1861. p. 431 (Misol).

1 ô, 2 q Sudest Island, 26. iii. 1916, 8. v. 1916 (Nos. 7317, 7421, 7422).

This species is new to the island, though known from the Louisiade group, where Meek collected it on St. Aignan. It breeds there and Meek obtained the eggs. 


\section{Cracticus lousiadensis Tristr.}

The adult female is exactly like the adult male, only smaller. The bill is slightly shorter. The wing in 6 fully adult males measured $168-171$, in 2 fully adult females $162-165.5 \mathrm{~mm}$. In both sexes there is sometimes an irregular small white spot in the middle of the breast, but more often it is wanting.

\section{Graucalus papuensis louisiadensis Hart.}

Graucalus hypoleucus louisiadensis Hartert, Nov. Zool. 1898. p. 524 (Sudest Island).

A fresh series fully confirms the differences of this subspecies. This as well as others are subspecies of papuensis. Cf. Rothschild \& Hartert, Novitates ZOOLOGiCAe, xxiii. p. 290.

\section{Edolisoma morio tagulanum Hart.}

Edoliosoma amboinense tagulanum Hartert, Nov. Zool. 1898. p. 524 (Sudest Island).

Some more specimens confirm the original diagnosis. Hartert now considers tagulanum and others to be subspecies of E. morio.

\section{Lalage karu pallescens Rothsch. \& Hart.}

Lalage karu pallescens Rothschild \& Hartert, Bull. B. O. Club, xxxvii. p. 17 (January 1917-St. Aignan and Sudest Islands. Type: Sudest).

Our latest study of the Lalage karu group with all our recent material showed the necessity of separating this form, the differences of which had already been noticed in 1898 .

\section{Monarcha cinerascens rosselianus ?}

Besides the two males collected in 1898 (both immature), we have now received three more specimens :

ô imm. Mt. Riu or Rattlesnake, Sudest Island, 24. iii. 1916. No. 7307.

ð. Sudest Island, 31.i. 1916. No. 7150 .

․ Sudest Island, 30.i. 1916. No. 7147.

The last two specimens appear to be fully adult, except for one to two of the larger upper wing-coverts, which are still brown, being remnants of the juvenile plumage, and that the base of the lower mandible is whitish in both, but in varying degree, and not sharply divided as in most adult $M$. cinerascens inornatus.

These specimens have given us some trouble. It is peculiar that of thirteen skins from Rossel Island not one has a whitish base to the under mandible, not even an immature bird. It is therefore not impossible that the form from Sudest differs in this respect from true $M$. cinerascens rosselianus, but more likely this pale base of the mandible is a remnant of the juvenile age.

In Novitates Zoologicae, 1915, p. 34, we have already called attention to the fact that a series from Dampier Island had the bases of the bill lightcoloured, though at least two showed no other trace of youth. But in that case, too, we had not sufficient evidence to show that this is a racial peculiarity.

We have this time not received any specimens of Monarcha melanopsis from Sudest Island, of which a pair were taken in 1898. There is no doubt that M. melanopsis has sometimes a grey throat and then looks almost exactly like 
$M$. cinerascens inornatus, but at present we are not quite sure what these specimens are. They may be birds in non-breeding plumage, or they may be immature, though not in the first plumage. They are certainly not the females, and in fact our dates do not prove that they are from any definite season. Such grey-throated birds can be distinguished from $M$. cinerascens inornatus by the following characters: The bill is smaller. There is a whitish or pale semicircle in front of the eyes. The second primary is longer, surpassing the secondaries and being like the 7 th or more frequently between the 7 th and 8 th in length, or at least not appreciably shorter than the 8 th, while in M. . inornatus the second primary is shorter than the eight and generally also shorter than the longest secondaries.

The form from the islands in Geelvink Bay is M. c. geelvinkianus A. B. Meyer. William Doherty sent us 7 skins of this form from Mafor. It is closely allied to kisserensis.

Another subspecies seems to be the Ternate form, of which Doherty sent us five specimens. These birds are very similar to geelvinkianus but appear to be still paler, and the bill, as a rule, is a little smaller. Unfortunately nearly all the Mafor skins are in very bad condition or juvenile, so that comparison is difficult.

Of Monarcha melanopsis (p. 525) no fresh material has come to hand.

\section{Monarcha trivirgatus melanopterus Gray.}

Monarcha melanoptera Gray, Proc. Zool. Soc. London, 1858. p. 178 (Louisiade Arehipelago).

3 of, 4 ㅇ from Mount Riu or Rattlesnake, April and March 25th, 1916, Eichhorn Bros.

New to Sudest Island. Before this we had received it from Rossel and St. Aignan Islands.

\section{Monarcha guttula (Garn.).}

A further series of eight specimens does not show the bill to be any smaller. This species is widely spread (ef. Novitates Zoologicae, 1903, p. 456), and in a series of 70 specimens no local differences can be observed.

\section{Monarcha (Piezorhynchus) alecto lucidus (Gray).}

Myiagra lucida G. R. Gray, Proc. Zool. Soc. London, 1858. pp. 176. 192 (Louisiade Islands).

It has been shown by Sherborn and again emphasized by Mathews that the dates of publication of the Voyage de la Coquille are different, and not all 1826, as had been accepted. Plate XV., on which Garnot's Muscicapa chalybeocephalus is figured, did not appear till 1828, and therefore Temminck's Drymophila alecto is the earliest name and has precedence over chalybeocephalus. This is the more unfortunate, as there has been some doubt about the original locality of the real alecto, which was erroneously stated to have come from Celebes, where it does not occur.

Our Sudest birds, of which we have again received some females, have somewhat variable bills, and those of the few St. Aignan specimens are partly even larger.

Temminck, Pl. Col. Ois. livr. 72 (not 70 as Mathews quotes, and in Vol III., not IV.!) pl. 430, 1827, says he had two specimens from Reinwardt from Celebes. 
Dr. van Oort kindly informs me that the two specimens collected by Reinwardt are in the Leyden Museum, and that one is from Timor, the other Ternate. As the species does neither occur in Celebes nor in Timor, the correct terra typica for alecto is Ternate!

[Mathews (Austral Avian Record, i. p. 126, 1912) has not only accepted Celebes as the terra typica, while the species does not occur on that island, but he says that he compared the Cape York specimens "with Celebes birds." This is impossible, as there are no Celebes birds! If Mr. Mathews says that the Cape York birds are "abundantly distinct" from Celebes specimens, he probably compared Papuan skins, which are indeed very different, and his "typical birds" were probably Papuan ones, as he says the new subspecies has a narrower bill and a longer wing. If he had compared the Cape York examples with typical Australian nitidus he could hardly have said this, because there is no difference, except that our Cape York examples have slightly shorter wings, a character which, however, requires confirmation by a larger series. Why, therefore, did Mathews not compare his Cape York form, which in 1912 he calls Monarcha alecto campbelli, and one year after Piezorhynchus alecto campbelli, with the Australian nitidus ? As, according to our specimens and judging from Mathews's words, his campbelli is nearest to nitidus, comparison with the latter alone would have been instructive.]

\section{Myiagra cyanoleuca Vieill.}

Platyrhynchos cyanoleucus Vieillot, Nouv. Dict. d'Hist. Nat. xxvii. p. 11 (1818-"Timor" ! Errore, substituted corr. locality N.S. Wales, Mathews, Austr. Arran Rec. ii. p. 97. Cf. Pucheran, Arch. Mus. d'Hist. Nat. Paris, vii. p. 358).

Myiagra nitida Gould, Syn. B. Austr. pt. iv. App. p. 1 (1838-"New South Wales and Van Diemen's Land,").

Myiagra nupta Hartert, Nov. Zool. 1898. p. 526 (Sudest Island).

It is not often that we find the same forms of purely Australian small Passerine birds in Australia and the Louisiades, while they are absent from New Guinea. This, however, is one of those cases, though possibly $M$. cyanoleuca may yet be discovered in New Guinea, as it is also found on Woodlark Island and the D'Entrecasteaux group (Fergusson Island). Specimens from Sudest Island are indistinguishable from Australian ones.

\section{Myiagra rubecula sciurorum subsp. nov.}

We are obliged to separate the Myiagra from Sudest Island, under the above name, for the reasons explained below, but in order to do so we found it necessary to review all the allied forms. We were greatly assisted in this by $\mathrm{Mr}$. G. M. Mathews lending us a series of 80 specimens from Australia, including three of his types. We have at last come to the following conclusions :

Myiagra rubecula (Todus rubecula Latham, 1801) was described from New South Wales, Myiagra concinna Gould, 1848, from Port Essington. As in each of these two localities only one form is found, we can apply these names with certainty. Mr. Mathews treats concinna as a subspecies of rubecula, but this view cannot be upheld, as at Cape York and a great part of (Northern) Queensland rubecula and concinna occur, at various seasons, side by side. This is surprising, as the two species are so much alike, in fact more so than the two 
Marsh-tits (Marsh- and Willow-tit), which have been united for so many years, more so than the two Tree Creepers of Central Europe (Certhia familiaris and brachydactyla), and as much as the two Calamoherpe (i.e. strepera and palustris). In fact, the only difference which we have found between the males is, that the male of $M$. rubecula has the lores deep grey or slate-colour, that of concinna has them velvety black, and the lores are in the latter connected by a narrow black line across the forehead, just above the bill, while this line is not conspicuously developed in $M$. rubecula. Moreover, the bill is generally wider in rubecula, narrower in concinna. There is apparently no difference at all between the females, except that there as well the bill is as a rule narrower in concinna, wider in rubecula; this difference in the bill is quite evident if good series of males (and females as far as they are certain, i.e. coming from localities where only one of the forms occur) are compared, but it is variable and not easily measured. We agree with Mathews that Platyrhynchos ruficollis Vieillot, Myiagra rubicoloides Vig. \& Horsf., and Myiagra plumbea of the same authors, all from N.S. Wales, are synonyms of rubecula, and to these we must add $M$. rubecula ringwoodi Math., as the supposed difference, i.e. "much greyer upper surface" does not hold good. Mathews also described a Myiagra rubecula yorki, of which he thought that it was smaller, wing $75 \mathrm{~mm}$. This he described erroneously, as some Cape York specimens are rather long-winged, with a wing of fully $80 \mathrm{~mm}$., while many, if not more than half the typical rubecula have wings no longer and sometimes even shorter than $75 \mathrm{~mm}$. Moreover, the type of M. yorki (collected at Cape York by A. S. Meek's brother-in-law Eichhorn on July 9th, 1898, No. 1900 of the Meek collections) is a black-lored concinna! It should, however, provisionally be kept separate, because it has the bill on the average wider than typical concinna, and, as a rule, about as wide as in rubecula. At Cape York occur also $M$. rubecula with slate-grey lores, which we are not able to separate from rubecula of New South Wales. The wings of the few males (two very worn ones and three in fresh plumage) measure 75 to at least $78 \mathrm{~mm}$. M. rubecula melvillensis and broomei Math. are concinna and, in our opinion, in no way separable.

Then there is a form of $M$. rubecula from British New Guinea. We have of it three males, one from Nicura (Lix coll.), one from the Aroa River (A. S. Meek), one from the Kumusi River (A. S. Meek), and one female, and we have seen two females in the British Museum.

This form we must separate as a new subspecies, The lores are grey, even lighter than in typical rubecula, in fact not much darker than the crown, the upperside a shade paler, especially on the crown. Wings $71,73,745 \mathrm{~mm}$. The female has the throat perhaps of a darker brown, the upperside rather pale, wings $71,72,73.8 \mathrm{~mm}$. We name this form :

\section{Myiagra rubecula papuana subsp. nov.}

Type in the Tring Museum, ô ad., Kumusi River, North-Eastern British New Guinea, 28. vii. 1907 . A. S. Meek coll., No. 3322.

The Myiagra from Sudest and Rossel Islands have slate-coloured lores and frontal line (not black as in concinna!), and the males are exactly like the latter, except that the head, especially the throat, is generally somewhat darker, almost steel-blue. But the females have the jugular region rather darker, browner, the chin in contrast, as a rule, more whitish, sometimes quite white. This latter 
character varies in rubecula, but the chin is almost always less whitish, sometimes quite as brownish as the jugulum. We propose to call this form :

Myiagra rubecula sciurorum subsp. nov.

for the brothers Eichhorn (Eichhorn=sciurus).

Type : $\subsetneq$ ad. Rossel Island, 3. iii. 1898. A. S. Meek coll., No. 1532.

The wings of our 8 males from Sudest and Rossel Islands measure 73.5-77 mm., females $70^{\circ} 5-75$, but most of them are not quite adult, showing still white tips to the greater upper wing-coverts.

Compared with these the birds from St. Aignan Island seem to be larger, measuring: $\widehat{o} \hat{o}$, wing 80,82 ; $+9,75,75,75.5 \mathrm{~mm}$. There are, on the other hand, similar differences in size in Australia, and we cannot, therefore, regard our small series from St. Aignan as large enough to prove that their larger size is anything more than accidental. Their coloration is exactly as in $M$. r. sciurorum.

The bill of Sudest Island males is described on the labels as dark slaty blue with black tip, iris dark brown, feet black. Females: "Iris dark brown. Bill black and light horn-colour. Feet blackish slate-colour."

We therefore recognize at present of this group of Myiagra:

Myiagra rubecula rubecula (Lath.).

Victoria, N.S. Wales, and Queensland as far north as Cape York.

Myiagra rubecula papuana $\mathbf{R}$. \& $\mathbf{H}$.

South-eastern New Guinea. (There are some specimens in the British Museum from the islands in Torres Straits which require further study, if possible from larger series.)

Myiagra rubecula sciurorum $\mathrm{R}$. \& $\mathrm{H}$.

Rossel and Sudest, and probably St. Aignan, Louisiade group.

\section{Myiagra concinna concinna Gould.}

Northern Territory and N.W. Australia.

Myiagra concinna yorki Math.

Northern Queensland from Cape York to at least as far north as Mackay. (See remarks.)

Gerygone magnirostris tagulana subsp. nov.

Formerly we had no Gerygone from Sudest Island, but now the brothers Eichhorn have sent us nine good skins, shot on Mt. Riu or Rattlesnake from January to April 1916. These, as one would have expected, belong to a new subspecies. Compared with G. magnirostris onerosa Hart. from St. Aignan they have a smaller bill, darker, duller, less rusty upperside and a less yellowish brown, more whitish under-surface. G. magn. rosseliana has the underside, except the throat, yellow. The nearest form is G. magn. conspicillata from N.W. New Guinea, but G. m. tagulana has a more greyish olivaceous tinge on the upperside 
and the bill appears to be, as a rule, from one-half to one $\mathrm{mm}$. longer. They differ from the form inhabiting Fergusson Island (D'Entrecasteaux group) in being a little larger, above darker, browner, without a greenish tinge, the brownish tinge on the underside duller, paler.

The upperside of G. m. tagulana is sombre brown, brighter, and with a yellowish rusty tinge on the upper tail-coverts. The wings are blackish brown with olivaceous brown outer and pale, often whitish, brown inner edges. Tail olivaceous brown with a wide black ante-apical bar and a black tinge towards the base of the inner webs; fresh skins have also a small light spot on the inner web, immediately behind the black bar. The throat is white, rest of under-surface buff, brightest on breast and belly and under tail-coverts, middle of underside nearly white. "Bill black, iris dark red, brownish red, light brown, greyish brown (!). Feet slate-blue" (Eichhorn Bros.). Some, probably more juvenile, specimens have the underside, including the greater part of the throat, buff. Wing 55-57, in one of the birds marked o only $54 \mathrm{~mm}$. Tail $40.5-42 \mathrm{~mm}$.

Habitat. Sudest Island, Louisiade group. Type : ot ad. Mt. Riu or Rattlesnake, Sudest, 20.iv. 1916. Eichhorn Bros. leg. No. 7565 of the A. S. Meek collections.

We make use of this opportunity to name another subspecies, that from Fergusson Island. It is very closely allied to $G$. magnirostris magnirostris of Australia, but the upperside is richer, the underside much more buff. Wings $52-55 \mathrm{~mm}$. We call this form-

Gerygone magnirostris proxima subsp. nov.

Type: ô Fergusson Island, 3. i. 1895, A. S. Meek coll. No. 1. Eight skins compared.

Ptilotis analoga vicina Rothsch. \& Hart.

Ptilotis analoga vicina Rothschild \& Hartert, Nov. Zool. 1912. p. 203 (Sudest Island).

Some fresh specimens confirm the differences stated by us.

There are, however, two misprints or slips in our former notes. In NovITates Zoologicae, 1898 , p. 527, under Ptilotis notata, No. (2), the sentence should read :

"The yellow line below the eyes, which is distinct, yellow, broader, and almost running into the auricular patch in those from Fergusson Island, is narrower, less distinct, very pale yellowish, and quite separated from the yellow auricular patch in the birds from Sudest."

In Novitates Zoologicae, 1912, p. 203, under $P$. analoga analoga, the middle sentence about the "Cape York form " is not quite correct. There are undoubtedly two forms at Cape York, a smaller one, gracilis, and a larger one, notata-evidently two species-and our comparison must have been made with specimens of gracilis, as the bill in notata is not smaller, but larger.

Philemon novaeguineae tagulanus subsp. nov.

Our former collection contained no specimens of a Philemon, but in this last collection were three very fine examples, all sexed as males.

They are nearest to $P h$. novaeguineae brevipennis $\mathrm{R}$. \& H. (cf. Novitates Zoologicae, 1913, p.-513) from the lower ranges of the Snow Mountains in 
Dutch New Guinea, but the bill is much shorter even than in females of the latter, and the knob is smaller. Moreover, the underside is much darker. The breast and abdomen are more greyish brown, of about the same colour as in the much larger subtuberosus from Fergusson and Goodenough Islands. Even if the three specimens should be females (which we have no reason to suppose), they would be of a quite distinct new subspecies. The bills measure $35^{\circ} 6-38$, the wings 142-143 $\mathrm{mm}$.

Type: of ad. Sudest Island, 6.v. 1916. Eichhorn coll. No. 7411 of the A. S. Meek collections.

"Iris dark reddish brown. Bill black. Feet slate-colour."

Mr. Ogilvie-Grant, Ibis, Jubilee Suppl. ii. p. 78 (1915), expresses his opinion that two of the subspecies which we had recognized in 1913, viz. brevipennis and aruensis, are not recognizable. His view about brevipennis is not correct and his own measurements rather support our separation of this form, but he only measured four males of $P$. novaeguineae novaeguineae. In our series the wings of males run up to 166 and $167 \mathrm{~mm}$., a length which is never approached in brevipennis. With regard to aruensis we expressed ourselves (l.c. p. 514) rather hesitatingly, only saying that we were inclined to separate it, but we now believe that it should be separated, though it is close to $P$. n. novaeguineae. OgilvieGrant says: "The difference in the colour of the head used as a character is non-existent." We mentioned that the heads of aruensis " are after all generally much paler," and that is a fact, though sometimes no difference is visible. But there is another character which requires attention: the knob in aruensis rises more gradually, so that it becomes longer and the beak in front of the knob higher, whereas in novaeguineae it rises more abruptly so that there is a much sharper declivity in front of it. This is very obvious in the series, though a few specimens intergrade in this respect and are not distinctly separable on this character alone.

\section{Erythrura trichroa goodfellowi O.-Grant.}

Erythrura trichroa goodfellowi Ogilvie-Grant, Bull. B.O. Club, xxix. p. 29 (1911-Moroka Mountains) ; R. \& H., Nov. Zool. 1915. p. 36.

One male from Mt. Riu or Rattlesnake, 25. iii. 1916, No. 7316, agrees with our series of about 20 adults from British New Guinea and Vulcan and Dampier Islands. "Iris dark brown with ashy blue outer circle. Bill black. Feet light transparent brown."

\section{Alcedo atthis pelagica Stres.}

[Gracula atthis Linnaeus, Syst. Nat. ed. x. I. p. 109 (1758-Egypt. Ex Hasselquist, iter. Cf. Laubmann, Verh. Orn. Ges. Bayern xii. 4, p. 238. 1916).]

Alcedo ispida pelagica Stresemann, Nov. Zool. 1913. p. 316 (Eastern New Guinea, D'Entrecasteaux and Louisiade Islands).

Wings $68^{-70^{\circ}} 5$, in one male, however, $73 \mathrm{~mm}$. This form was separated by Stresemann on account of a shorter average of the wing, which he measures 66-72, but he had overlooked the ot with a wing of $73 \mathrm{~mm}$. As the nearest form, A. atthis hispidoides Less., has the wing 68.5-75 $\mathrm{mm}$.; our pelagica has it only about $2-2.5 \mathrm{~mm}$. shorter. Twenty-one pelagica were compared with 57 hispidoides.

It is of course very important to register even such small differences in size, 
and American writers are naming numerous subspecies on account of similar average differences in size (length of wing), but they should, in our opinion, only be considered sufficient for new names if large series are measured. Small series of 5 or 6 skins are not warranting the creation of new names, if they differ only in a similar way. Whether 21 (compared with 57) are to be considered sufficient may be questioned. The overlooking by Stresemann of the fourth skin of our former collection, with a wing of $73 \mathrm{~mm}$., which, as it happens, at once surpasses his maximum, shows how deceptive small series can be, though in this case it does not materially alter Stresemann's figures.

\section{Caprimulgus macrurus meeki subsp. nov.}

The Goatsucker of Sudest Island is nearly allied to the form from New Guinea, but darker, especially on the crown which is browner and darker, not so greyish, and on the middle tail-feather. We have now received another four specimens, viz. two fine adult males, one immature moulting male, and one adult female. The wings of the two males measure 182 and 184, that of the female $181 \mathrm{~mm}$. "Iris dark brown. Bill black. Feet dark walnut brown" (Eichhorn). This nice new form differs from the Bornean form in its shorter wing and uniform, more rufescent, less whitish ground-colour of the abdomen, but resembles it very much on the upperside. Perhaps it will be found that the white tips to the lateral rectrices of the males are generally longer than in most forms, as in our two adult males they measure 55 to $60 \mathrm{~mm}$., the latter measurement of which is not reached by New Guinea birds. Type of $C$. m. meeki: ot ad., No. 7397 of the Meek collection, collected on Sudest Island, 4. v. 1916, by one of the Eichhorns.

In Proc. U.S. Nat. Mus. xlviii. pp. 587 to 599, Mr. Oberholser published a valuable review of the "races of the long-tailed Goatsucker." This review is, however, hardly on a par with some of his other reviews, as, for example, that of the Collocalia and Butorides, as his material of Caprimulgi was very meagre, especially with regard to India and the Papuan Islands. Arthur Goodson has now geographically arranged our series, and we came to the following conclusions, without referring to the forms from the Indian mainland, which must be studied in the British Museum, as our material is insufficient for that purpose.

\section{Caprimulgus macrurus macrurus Horsf.}

Caprimulgus macrurus Horsfield, Trans. Linn. Soc. London, xiii. p. 142 (1821-Java).

Possibly C. m. macrurus may be restricted to Java, and probably Bali, but we cannot be quite sure about this at present. Unfortunately we have no series from Java, only a young male in moult and an adult female in poor condition, both collected by Ernst Prillwitz. Two skins from Java in the British Museum have the chin rufous and the chest more rufescent than the Bornean specimens, in which the chin is more blackish and the chest more whitish. It is therefore not improbable that the Bornean race can, after all, be separated, in which case it must be called :

\section{Caprimulgus macrurus salvadorii Sharpe.}

Oberholser unites the Javan and Bornean birds and with them also those from Palawan and the Calamianes. From the latter islands we have not seen 
any specimens, but from Palawan we have an adult male and a female, besides some juveniles. In colour our Palawan birds are slightly darker, the underside more brownish, while of the two Palawan skins in the British Museum one has the chin almost, the other quite as rufous as in the Javan examples. The wings of our adult Bornean birds measure : 0180 , $q$ apparently only 175 , while in our Bornean males they vary from 184-194, +188 , and that of the Javan adult female $179 \mathrm{~mm}$. It is thus possible that the Bornean race is somewhat larger, but we must for the present provisionally accept Oberholser's view, i.e. to unite the Javan, Bornean, and Palawan birds as C. macrurus macrurus Horsf.

\section{Caprimulgus macrurus oberholseri subsp. nov.}

A series of four males from Lombok and Sumbawa differs strikingly from typical macrurus: the upperside of the body is only slightly more rufescent, but the underside is decidedly more rufescent, especially on the upper throat and chest, but also on the abdomen. The outside of the wings is also more rufous. With these birds agrees perfectly an adult male from Salayer (November 1895, A. Everett leg.), and a female from Djampea (14.xii. 1895, A. Everett leg.) appears to be also the same. Wings: of Lombok 188, of Lombok 192, o Sumbawa $188 \mathrm{~mm}$. The other specimens moulting. of Salayer wing $184^{\circ} 5$ $\mathrm{mm}$.

Type: ô ad. Lombok, 1,500 feet, vi. 1896. A. Everett leg.

Caprimulgus macrurus mesophanis Oberh.

Caprimulgus macrurus mesophanis Oberholser, Proc. U.S. Nat. Mus. xlviii. p. 590 (1915-Amboina).

It was a daring proceeding to describe this bird from one single specimen, but our material confirms its distinctness, which is not one of size. The colour of C. m. mesophanis is more like that of oberholseri, and may be said to be somewhat intermediate between the latter and $l . m$. macrurus; the upper throat is reddish, the abdomen darker, more rufescent than in $C . m$. macrurus, but not so bright as in oberholseri, the barring narrower than in C. macrurus, about the same as in $C . m$. oberholseri. The wings of 8 males measure 184-192, i.e. by no means larger than Bornean specimens!

This form inhabits probably all the Moluccan Islands proper. We have it from Amboina, Ceram, Ceram Laut, Buru, and Obi.

Caprimulgus macrurus kuehni subsp. nov.

4 ó, 1 f from Tual, Little Key, Key Islands, the males collected in May, the female in October, by the late Heinrich Kühn, are nearest to the Moluccan form, but the bars on the abdomen are generally narrower and the wings are strikingly shorter. Those of the males measure only $175-177 \mathrm{~mm}$., that of the female is in moult, but its wing is probably only a little longer than $170 \mathrm{~mm}$.

Type: ô ad. Tual (Toeal), 10. v. 1898. Heinrich Kühn leg. No. 761.

Caprimulgus macrurus yorki Math.

Caprimulgus macrurus yorki Mathews, Nov. Zool. xviii. p. 291 (1912-Cape York, Northern Queensland).

We have a large series of Goatsuckers of this species from New Guinea, i.e. from various parts of British New Guinea and the foot-hills of the Snow 
Mountains, also a male from Andai, Arfak Peninsula, a young bird from Humboldt Bay, and an adult female collected at Korrido, October 1896, by William Doherty. The latter, unfortunately in very bad condition, appears to be darker, but all the others agree well with two skins from Cape York. We do, therefore, not hesitate to call all the Papuan birds before us Caprimulgus macrurus yorki. From the examination of one skin from Northern Territory the supposed C. $m$. keatsi Mathews (Novitates Zoologicae, xviii. p. 291) seems to us to be the same as yorki. This would also seem to be confirmed by Oberholser, who unites the New Guinea birds with keatsi, while we find it identical with yorki, having only one topotypical keatsi before us, which we cannot either distinguish.

As we have said before, we do not, at the moment, intend to discuss the continental Indian forms of $C$. macrurus, but we must express our doubts regarding C. macrurus anamesus Oberholser (Proc. U.S. Nat. Mus. xlviii. p. 598, described from "Singapore and Sumatra"). Though we have no specimen from Singapore Islands, we cannot help doubting that a different race from that of the Malay Peninsula proper inhabits it, the island being so near the mainland, and because two females, collected by Ernst Hartert in Deli, Sumatra, agree beautifully with skins from the Malay Peninsula.

Oberholser's rediscovery of Peale's name bimaculatus would result in the C. macrurus ambiguus Hart. becoming C. macrurus bimaculatus Peale, if only one form inhabited N.E. Sumatra and the Malay Peninsula. Oberholser, however, is of opinion that two Malayan forms of macrurus can be recognized : one occurring in the Malay Peninsula and Indo-China, which he argues is C. m. bimaculatus, C. $m$. ambiguus Hart. being a synonym, the other in Singapore and Sumatra, which he supplies with a new name, $C . m$. anamesus, terra typica Singapore. This reasoning - as has already been pointed out by C. Boden Kloss (Ibis, 1918, p. 95 - is wrong. The type of $C$. bimaculatus came from Singapore and not from Malacca town ; apparently Oberholser is not aware that the name "Malacca" is applied in most continental languages not to Malacca town only, but to the whole Malay Peninsula, and was used in the same way by English writers at least during the first half of the eighteenth century. Therefore the statements of the type of $C$. bimaculatus coming from Singapore and Malacca agree, Singapore being part of what was called Malacca. The supposed differences between bimaculatus and anamesus are merely those of size, but (cf. Kloss, Ibis, 1918, p. 96) it is very doubtful if they really exist, if more material is examined. In any case anamesus would be a clear synonym of bimaculatus, both being described from Singapore. If two forms exist in the Malay Peninsula, the northern one will have to be called ambigurs, since C. Boden Kloss has restricted the latter name to birds from Southern Tennasserim (Ibis, 1918, p. 96).

Caprimulgus macrurus meeki Rothsch. \& Hart.

See anteà.

Sudest, Louisiade Islands.

Caprimulgus macrurus albolaxatus subsp. nov.

In Cat. B. Brit. Mus. xvi. p. 538 attention has already been called to the great extent of white on the outer rectrices of two males from New Britain. This difference is not accidental, as it occurs also in males from Vulcan Island 
and Dampier Island. In adult males from New Britain in the British Museum the white tip to the outer tail-feather is 65 to $70 \mathrm{~mm}$. long, and the white spot on the outer primaries is larger, on the outermost one extending almost or quite to the shaft. In New Guinea males the white to the outer rectrices is not longer than 45 to $56 \mathrm{~mm}$. and the white on the outermost primary is less wide, remaining away from the shaft several millimetres, and only exceptionally almost reaching it. There is only one somewhat disturbing bird in the British Museum, said to be a male and from Blanche Bay, New Britian, from the Layard collection. The white on the outer rectrix is only $59 \mathrm{~mm}$. long, and the white on the first primary does not quite touch the shaft. Even here the white is, however, wider than in New Guinea males.

Now, our male from Vulcan Island has the white tip to the lateral rectrix $64 \mathrm{~mm}$. long and the white on the first primary practically touches the shaft. It is therefore evident that the Goatsucker inhabiting the chain of islands from New Britain to Vulcan (Manumudar, Volcano) Island must be separated. Our male from Dampier Island, though in heavy moult and with first primaries and lateral rectrices only beginning to grow, appears also to belong to this subspecies. In general colour it agrees with the birds from New Guinea. Wings: of 183, 187, 190 , 우 $178 \mathrm{~mm}$.

We name this race:

Caprimulgus macrurus albolaxatus.

Type: ${ }^{\star}$ ad. Volcano (Vulkan, Manumudar) Island, 27.xi.1913. No. 6294 of the Meek collections. (Cf. Novitates Zoologicae, 1915, pp. 33, 43.)

\section{Halcyon sordida colonus Hart.}

Halcyon sordidus colonus Hartert, Nov. Zool. 1896. p. 244 (Egum group and Louisiade Is., type Egum).

Two males, neither of them fully adult, were obtained on February 8th and 27th by the Eichhorns. Nos. 7191, 7271 of the Meek collections.

New to Sudest Island.

Halcyon macleayii Jard. \& Selby.

Halcyon Macleayii Jardine \& Selby, Ill. Orn. ii. pl. 101 and text (1830-New South Wales, teste Mathews. Originally no locality given, but readers can suppose Australia).

2 ô, 2 ㅇ, all shot in May, 1916. Nos. 7398, 7399, 7405, 7406. " Iris dark brown. Bill black, base of lower jaw white. Feet black."

New to Sudest Island.

Halcyon saurophaga Gould.

IIalcyon saurophaga Gould, Proc. Zool. Soc. London, 1843. p. 103 ("New Guinea." Type in Brit. Mus.).

One female obtained in February, No. 7272.

Also new to the island.

\section{Lorius hypoenochrous hypoenochrous Gray.}

We have again received a series of this beautiful Parrakeet, from Mt. Riu. The species was originally described from a Sudest Island skin, type in the British Museum. 
As Hartert already said, Novitates Zoologicae, 1898, p. 530, the St. Aignan specimens are somewhat intermediate, showing mostly no real black bar on the under wing-coverts, but there is also one specimen from Sudest in which the black bar is only indicated, while in typical $L$. $h$. devittatus Hart. it is quite absent, and the latter is also larger, with a more powerful bill and gencrally much longer wings.

\section{Geoffroyus aruensis sudestiensis de Vis.}

We have again received several specimens, among them some that are evidently fully adult females. These latter have the crown dark green like the back, not brown!

\section{Ninox goldii Gurn.}

Ninox goldii Gurney, Ibis, 1883. p. 171 (S.E. New Guinea). This locality is almost certain to be erroneous. It seems that $N$. goldii does not occur in S.E. New Guinea at all, but is an island bird. Like other birds received from Goldie and collected by Hunstein-cf. Pitta finschii, Pachycephala fortis, Phonygammus hunsteini-Ninox goldii, though said to have come from "S.E. New Guinea " - a term at that time evidently including the D'Entrecasteaux group -and sometimes labelled in the British Museum "Astrolabe Mts.," must have come from

Fergusson Island. The original spelling is goldii, not goldiei.

Ninox rosseliana Tristram, Ibis, 1889. p. 557 (Rossel Island).

We have again received two fine specimens from Sudest Island. Now, these as well as all the other four received previously from that island are underneath more whitish and have the thighs lighter, more yellowish than rufous, compared with four skins from Rossel Island, which again have the thighs a little brighter rufous, not quite so brown as in the Fergusson and Goodenough specimens. The differences, however, are not quite constant, the underside being alike in a bird from Sudest and those from Rossel and the D'Entrecasteaux Islands, and the thighs of one Rossel bird are hardly darker than in some from Sudest, while the difference between Rossel and D'Entrecasteaux specimens are altogether negligible. It will therefore, for the present, be safer to unite all these birds under the name goldii.

The iris of adult Sudest Island birds is marked as bright yellow and golden yellow.

(In the Ibis, Suppl. ii. 1915, p. 257, Mr. Ogilvie-Grant made some remarks on $N$. theomacha, terricolor, and goldii. He quite correctly pointed out that Sharpe wrongly united goldii with the other two forms, and this was already shown by Hartert in Novitates Zoologicae, 1896, p. 246. On the other hand, $N$. theomacha and terricolor, which Mr. Ogilvie-Grant separates as two species, are not distinct, at least not for the reasons given by the latter, the spots on the belly varying not only from white to buff but are sometimes even absent).

The following species must be added to the fauna of Sudest :

\section{Astur poliocephalus (Gray).}

1 immature $\hat{o}, 25$. ii. 1916. 
Haliastur indus girrenera (Vieill.).

$1 \uparrow($ ef. Novitates Zoologicae, 1914, p. 210 ).

Pandion haliaëtus cristatus (Vieill.).

1 ô ad., 25.i. 1916.

Carpophaga pinon salvadorrii Tristr.

4 oิ 우 ad.

Columba metallica halmaheira (Bp.) (?)

1 o ad., Mt. Riu or Rattlesnake, 15. iii. 1916. This specimen differs from typical birds by its size (wing $252 \mathrm{~mm}$. !) and a strong development of the purple gloss above and below. Specimens from Rossel Island are like others from the Papuan Islands, New Guinea, and Moluccan Islands.

Chalcophaps chrysochlora chrysochlora (Wagl.).

1 ô ad., 11.ii. 1916.

Megapodius duperreyii macgillivrayi Gray.

6 ơ + ad., 1 juv.

Demigretta sacra (Gm.).

$\hat{o}+$ ad., light and dark variety, the white and blue-grey forms being undoubtedly one and the same species. No subspecies separable.

\section{Porphyrio melanotus melanotus Temm.}

1 fine adult $\hat{o}, 7 . v .1916$. As far as one can see from a single specimen this bird agrees perfectly with typical Australian melanotus.

The following migratory Waders are also new to Sudest Island:

Tringa hypoleuca L.

Tringa incana brevipes (Vieill.).

Charadrius leschenaultii Less.

Charadrius dominicus fulvus Gm. 


\section{$2 \mathrm{BHL}$ Biodiversity Heritage Library}

Rothschild, Lionel Walter Rothschild and Hartert, Ernst. 1918. "Further notes on the birds of Sudest Island, or Tagula, in the Louisiade Group." Novitates zoologicae: a journal of zoology in connection with the Tring Museum 25, 313-326. https://doi.org/10.5962/bhl.part.29769.

View This Item Online: https://www.biodiversitylibrary.org/item/24178

DOI: https://doi.org/10.5962/bhl.part.29769

Permalink: https://www.biodiversitylibrary.org/partpdf/29769

\section{Holding Institution}

Natural History Museum Library, London

\section{Sponsored by}

Natural History Museum Library, London

\section{Copyright \& Reuse}

Copyright Status: Public domain. The BHL considers that this work is no longer under copyright protection.

This document was created from content at the Biodiversity Heritage Library, the world's largest open access digital library for biodiversity literature and archives. Visit BHL at https://www.biodiversitylibrary.org. 